\title{
The exchange of letters in early Sufism: A preliminary study
}

\author{
Arin Salamah-Qudsi \\ University of Haifa ${ }^{1}$ \\ arinsq@gmail.com
}

\begin{abstract}
This paper introduces the exchange of letters in early Sufism, analyses the significance of these exchanges, and examines these documents not for their general literary qualities or for theoretical discussion of appropriate conduct but, rather, for actual data relating to personal and interpersonal relationships. Furthermore, this paper emphasizes the crucial need for creating a corpus of Sufi letters and pieces of correspondence. The discussion is divided into methodological and conceptual-historical perspectives. The methodological perspective includes a survey of sources, the question of transmission, letter fragment usage by later authors, and a reconstruction attempt of the actual circumstances of these documents. The conceptualhistorical perspective analyses content, rhetoric, argumentation forms, and self-representation.
\end{abstract}

Keywords: Rasāil, Mukātabāt, Fragments of letters, Ikhwāniyyāt, Überreste, Corpus of Sufi letters, Mațâli', Rasä̀il al-Junayd

\section{Introduction}

Exchanges of letters ( $\left.r a s \bar{a}^{\prime} i l\right)$ and correspondence (mukātabāt) during the early phase of Sufism, whether between Sufi figures or occasionally between Sufis and non-Sufis, have rarely attracted scholarly interest. Sufi works of the late third/ninth and fourth/tenth centuries provide us with an impressive number of fragments of early Sufi letters and pieces of correspondence. However, no corpus of this material has yet been generated. Sufis addressed letters to their counterparts over a wide variety of circumstances and purposes. An impressive number of letter fragments appear to have been taken from original and longer versions of correspondence that certain Sufis, prior to the tenth century, had addressed to each other; this period witnessed the composition of the great Sufi manuals. These letters were not written primarily for the purpose of recording mystical theories, but rather served particular purposes in their respective

1 The first draft of this paper was written during my stay at the Oxford Centre for Islamic Studies as Imam Tirmizi Visiting Fellow (2019). I wish to express my deep gratitude to the Centre's Director Dr Farhan Nizami and the Deputy Registrar, Dr Richard Yousif Weyers, for their support in ensuring all allocated office facilities and full access to the libraries and archives in Oxford. The final version of the paper was completed thanks to a research grant from the Israel Science Foundation (grant no. 514/19). 
historical period. The letters are generally undated and in many cases do not even include the addressees' names. The purposes of these letters were wideranging: they included instructing Sufi novices, providing pieces of counsel, resolving some enquiries and controversial issues, and even criticizing and debating with addressees. While, broadly speaking, the exchange of letters helped early Sufis establish their networks and cultivate their collective religious identity, the different circumstances that surrounded the letters' authorship need to be thoroughly investigated.

Unlike earlier Sufi letters and correspondence, letters produced after the fourth/tenth century were limited to a few scholarly endeavours. The correspondence of Sharaf al-Dīn Muhammad al-Balkhī with his master Majd al-Dīn al-Baghdādī (d. 616/1219) was the focus of Fritz Meier's paper in which he relies on the Köprülü manuscript (1589), translates the text into German and comments upon it. ${ }^{2}$ From the late sixth/twelfth century, the short letters of the Sufi sheikh of Baghdad 'Umar al-Suhrawardī (d. 632/1234) to some of his contemporaries including the renowned theologian Fakhr al-Dīn al-Rāzī (d. 606/ 1210) gained a brief reference in my book on the life and teachings of al-Suhrawardi $; 3$ the latter is an example of a Sufi letter addressed to a non-Sufi contemporary and is in itself an additional interesting aspect of this research. My reference to other of al-Suhrawardī's letters relies on different manuscripts from the Biblioteka Jagiellońska (Poland) and the Yehuda collection at The National Library, Jerusalem. Al-Suhrawardī's letter to al-Rāzī has been published by Pourjavadi. ${ }^{4}$ Another Sufi master, Ibn 'Arabī (d. 638/ 1240), used his letter to al-Rāzi to convert the latter to Sufism. ${ }^{5}$

William Chittick relied on a manuscript that he discovered in the Süleymaniye Library in Istanbul to draw attention to the Arabic correspondence of Qāọ̄i Burhān al-Dīn Aḥmad ibn Muhammad (d. 800/1398) with one member of the School of Ibn 'Arabī. ${ }^{6}$ In another work, Chittick examines Sadr al-Dīn al-Qūnawī’s (d. 673/1274) correspondence with Nașīr al-Dīn al-Ṭūsī (d. 673/ 1274). ${ }^{7}$ All these letters revolve around arguments of mystical theories and metaphysics.

Risāla (plural rasa $\bar{a}^{\prime} i l$ ) was a very common genre during the first centuries of Islam. As Albert Arazi and Haggai Ben-Shammay indicate, the Arabic term

2 See Fritz Meier, "Ein Briefwechsel zwischen Šaraf ud-dîn-i Balhî und Mağd ud-dîn-i Baghdâdî", Mélanges offerts à Henry Corbin, ed. Seyyed Hossein Nasr (Tehran: The Institute of Islamic Studies McGill University, Tehran Branch, 1977), 321-66.

3 See Arin Salamah-Qudsi, Bayna sayr wa-țayr: al-tanz̧ìr, hayāt al-jamā'a wa-bunā al-mu'assasa fì tașawwuf Ab̄̄ Hafș 'Umar al-Suhrawardī (Beirut: Dār al-Kutub al-'Ilmiyya, 2012), 554-9.

4 See N. Pūrjavādī, Dū mujaddid (Tehran: Nashr-i Dānishgāh, 2002), 515-7.

5 This letter was translated into French in Michel Vâlsan (trans.), "Épître adressée à l'imâm Fakhru-d-Dîn ar-Râzî”, Études Traditionnelles 366-7, 1961, 244-53. More recently, it was presented and translated into English by Mohammed Rustom, "Ibn 'Arabī's letter to Fakhr al-Dīn al-Rāzī: a study and translation", Journal of Islamic Studies 25/2, 2014, 113-37.

6 See William Chittick, "Sultan Burhān al-Dīn's Sufi correspondence", Wiener Zeitschrift für die Kunde des Morgenlandes 73, 1981, 33-45; MS. Ayasofya 2349.

7 William Chittick, "Mysticism versus philosophy in earlier Islamic history: the al-Ṭusī, al-Qūnawī correspondence", Religious Studies 17/1, 1981, 87-104. 
risāla appears in very ancient inscriptions of Arabia. ${ }^{8}$ While the term originally meant the oral transmission of a message, it took on the meaning of written text by the mid-third/eighth century. Works of $a d a b$, historiographies, and biographies provide us with an enormous number of letters addressed by men of authority to their opponents to debate political issues; examples of these are the letters of 'Alī ibn Abī Tạalib to Mu'āwiya ibn Abī Sufyān and other contemporaries. ${ }^{9}$ Other instances may be seen in correspondence from scholars and ascetics (zuhhād, singular zāhid) to their contemporaries or rulers who they aspired to counsel: examples may be found in the letters of al-Hasan al-Bașrī (d. 110/ 728 ), the renowned ascetic of Bașra, to one of his companions, ${ }^{10}$ or to the Umayyad khalīfa 'Umar ibn 'Abd al-'Azīz, as well as the exchanges between al-Hasan ibn 'Abd Allāh ibn Sa'̄̄d al-'Askarī, the famous lexicologist (d. 382/ 992), and al-Șāhib ibn 'Abbād the Buyid statesman. ${ }^{11}$ Risāla developed during the Umayyad period and denoted a "monograph", "treatise" or a "literary epistle" on particular religious, theological or philosophical issues. Hājjī Khalīfa (d. 1067/1657), while referring to the Rasä'il of Abū al-'Alā' al-Ma arrī (d. 449/1057), distinguishes between long rasä'il that serve as monographs, and short rasä il that serve as correspondence (mukātaba). ${ }^{12}$ Adrian Gully, in his work on the culture of letter-writing in pre-modern Islam, focuses primarily on letter-writing as part of artistic prose composition (insh $\bar{a}$ '). Gully proposes dividing what he calls "the epistolary genre" into two parts: official or formal letters, and informal letters (ikhwāniyyāt). As regards ikhwāniyyāt, Gully criticizes Arazi and Ben Shammay's definition of this genre which is seen as purely literary letters whose exclusive subject is deep affection for one's friends. According to Arazi and Ben Shammay, although these letters were usually prompted by a particular event such as the birth of a son or the death of a relative, the authors do not seek to discuss any particular event, but only to formulate and celebrate the motif of brotherly friendship. ${ }^{13}$ Gully argues that informal letters were not exclusively reserved for correspondence between friends; ${ }^{14}$ and insofar as my studies of Sufi letters are concerned, I agree with Gully. In these letters, while abstract literary contents concerning Sufi conduct, general manners and beliefs still occupy a prominent place, many of the letters go beyond displays of Sufi manners and include references to particular circumstances and networks that are not necessarily of

8 See A. Arazi, H. Ben Shammay, Munibur Rahman, and Gönül Alpay Tekin, "Risāla", in. P. Bearman, Th. Bianquis, C.E. Bosworth, E. van Donzel, W.P. Heinrichs (eds), Encyclopaedia of Islam, second edition, consulted 6 January 2020.

9 See Muhammad ibn al-Ḥusayn al-Sharīf al-Raḍī, Nahj al-balāgha, ed. Fāris al-Ḥassūn (Qom and Najaf: Markaz al-Abhāâth al- 'Aqā' idiyya, 1998), 482-3.

10 See MS. Ayasofya, 1849.

11 See Abū al-Hasan 'Al̄̄ ibn Yūsuf al-Qifțī, Inbāh al-ruwā 'alā anbāh al-nuhā, ed. Muhammad Abū al-Faḍl Ibrāhīm (Cairo and Beirut: Dār al-Fikr and Mu'assasat al-Kutub al-Thaqāfiyya, 1982), 1: 346.

12 See Ḥājjī Khalīfa, Kashf al-ẓunūn 'an asāmī al-kutub wa-l-funūn (Baghdad: Maktabat al-Muthannā, 1941), 1: 901.

13 See Arazi et al., Risāla.

14 See Adrian Gully, The Culture of Letter-Writing in Pre-Modern Islamic Society (Edinburgh: Edinburgh University Press, 2008), x. 
a friendly nature. These letters can, therefore, be considered neither purely literary nor restricted to the theme of friendship.

This paper has nothing to do with risäla as pure monograph, and it is limited to pieces of correspondence that were circulated among early Sufis. Nonetheless, separating risāla as a literary epistle from risāla as an actual letter is not easy. In the Sufi domain, this separation is especially difficult since structural constraints imposed by the literary genre very often influence the actual content, which is the practical message flowing from a particular historic moment and giving rise to writing the letter. The following discussion will further elaborate this idea.

Klaus Hachmeier's discussion of non-Sufi private letters and official correspondence written in Arabic under Buyid rule focuses on the value of these documents as historical sources and can shed light on our topic. For example, Hachmeier makes use of the term überreste, which was introduced earlier by A.V. Brandt to relate to "everything that has remained immediately and directly of the historical facts of events". Hachmeier places private and official letters produced during Buyid rule under a sub-category called "written überreste". This subcategory includes poetry as well as both private and official exchanges in the form of letters, messages, deeds, etc.: these have survived in three forms: (i) as original documents; (ii) as exchanges cited in other works; and (iii) in letter collections. ${ }^{15}$ In his most recent study, Hachmeier provides a more comprehensive survey of a large collection of letters written by Abū Ishāq Ibrāhīm al-Șābi (d. 384/994), the Buyid secretary, based on manuscripts and other sources. ${ }^{16}$

In a Sufi context, the verb kataba often appears before quoted letters leaving the impression that the term risāla denotes a written letter. Evidence of oral correspondence is documented but the terms risāla or rasä il are not used in these instances. A reference to such oral correspondence is documented concerning Dhū al-Nūn al-Mișrī (d. c. 245/859-860) and Fātima of Nishapur. ${ }^{17}$ Having said this, the current paper seeks to sketch the major outlines of the study of Sufi letters and is a preliminary attempt to prepare the ground for a comprehensive study of exchanges of letters in early Sufism. This preliminary research will relate to two perspectives: the first methodological and the second labelled "conceptual-historical" since it relates to contexts, contents and rhetoric.

From a methodological perspective, this paper seeks to examine the following questions: what are the types of sources in which these letters were preserved,

15 See Klaus U. Hachmeier, "Private letters, official correspondence: Buyid Inshä' as a historical source", Journal of Islamic Studies 13/2, 2002, 137-8.

16 See Klaus Hachmeier, "The letters of Abū Isḥāq Ibrāhīm al-Ṣābi': a large Buyid collection established from manuscripts and other sources", Mélanges de l'Université Saint-Joseph 63, 2010, 107-221.

17 See Abū 'Abd al-Raḥmān al-Sulamī, Dhikr al-niswa al-muta' abbidāt al-șūfiyyāt, in Rkia Elaroui-Cornell (ed. and trans.), Early Sufi Women (Louisville, KY: Fons Vitae, 1999), 143. On this occasion, it was narrated that Fạtima sent a rifq (a common term in early Sufi literature which indicates a wide range of donations, presents, alms, food and money that the Sufis used to receive from their supporters, both male and female) to Dhū al-Nūn al-Mișrī, who refused to take it and asked the messenger to tell the sender that "accepting women's support is a sign of humiliation and weakness" ( $f \grave{i} q u b \bar{u} l$ arfāq al-niswān madhalla wa-nuqșān). This follows Elaroui-Cornell's translation. See the reference to this anecdote in Arin Salamah-Qudsi, Sufism and Early Islamic Piety: Personal and Communal Dynamics (Cambridge: Cambridge University Press, 2018), 234. 
and how should these sources be treated? What methods should be used to research Sufi letters? Did all references to such correspondence indicate written forms of correspondence or were some acts of oral transmission? In other words, do terms like "he wrote to" (kataba ilā) always indicate written letters or might they also refer to oral contact? How are terms like "he wrote to" or "he addressed a letter to" in Sufi contexts understood when used in non-Sufi texts? Do Sufi letters differ in structure and style from non-Sufi letters? Is the use of particular Sufi terminology the only dividing feature? To what extent should traces of Sufi letters be a source with social or historical values? This last question has to do with both methodology and content.

From a conceptual-historical perspective, this paper aims to analyse the different forms of available letters, the particular theoretical discussions implied therein, and the identities and relationship between both senders and addressees. The paper will also examine certain philological issues of structure and semantics as they relate to this type of research. Finally, the paper will discuss the ways in which the study of Sufi letters should be able to enrich our understanding of early Sufi piety by taking a broad approach and incorporating an analysis of social frameworks as well as other thematic features. This will help establish the basis through which one may reconstruct the complexity of the dynamic networks in early Sufism. This type of research is intended to promote further studies of Sufism, in relatively new territory away from most studies of Sufi works which presently deal with abstract Sufi theories or the development of particular forms of piety and Sufi rituals such as $s a m \bar{a}^{\prime}$ and $d h i k r$. It will also help us reconstruct the development of early Sufi piety as a process motivated and dominated by people whose personal concerns, tensions and aspirations could not, and should not, be overlooked.

\section{Methodological perspective}

Methodologically speaking, the first step in this research project is to create a corpus of Sufi letters and pieces of correspondence that were written between Sufis and, on certain occasions, between Sufis and non-Sufis, between the late ninth and the thirteenth centuries. These letters should be distinguished from Sufi monographs or treatises holding the title risāla. This corpus would include complete texts of correspondence, fragments of letters and response letters in Sufi published works as well as unpublished manuscripts and non-Sufi biographies, historiographies and works of $a d a b$. This raises the following question: what does a survey of the major Sufi and non-Sufi sources reveal? The earliest source for what we mean by a Sufi exchange of letters is al-Junayd al-Baghdādī's (d. 298/910-911) letters to some of his contemporaries, which have come to us under the title of Rasäil al-Junayd. The vast majority of these letters, based on the manuscript of Șehit 'Ali (1374) were edited and published by Abdel-Kader. ${ }^{18}$ Meanwhile many references to other letters written by al-Junayd and response letters addressed by others to him are provided in many

18 See Ali Hassan Abdel-Kader, The Life, Personality and Writings of al-Junayd: A Study of a Third/Ninth Century Mystic with an Edition and Translation of His Writings (London: Luzac \& Company, 1962). 
works including those of al-Sarrāj (d. 378/988), al-Khargūshī (d. 407/1016), Abū Nu'aym al-Ișfahān̄̄ (d. 430/1038), and al-Qushayrī (d. 465/1073). Abdel-Kader does not seem to be concerned about the very structures of al-Junayd's letters. His main concern is directed to the Sufi worldviews and doctrines of al-Junayd. In 1978, Muhammad Mușțafă published an edition of the previously published writings of al-Junayd in addition to some unpublished material. He was the first to publish response letters addressed to al-Junayd by some of his contemporaries such as Yūsuf ibn al-Husayn of Rayy (d. 304/ 916-917). Mușțafā adds a long introduction to his edition in which he describes al-Junayd's life and historical context, and presents a detailed survey of his letters and treatises on different Sufi issues. The sections dedicated to al-Junayd's letters or the introductory sections of his letters in the two editions of Su'ad al-Hakīm and Ahmmad Farīd al-Mizyadī rely on Abdel-Kader's edition as well as al-Sarrāj's Kitāb al-Luma' and Abū Nu'aym al-Ișfahānī’s Hilyat alawliy $\bar{a}^{\prime}{ }^{19}$ This interest in al-Junayd's letters was a very significant contribution to the study of early Sufism; however, a further process of creating and analysing a larger corpus of correspondence that goes beyond al-Junayd, and includes more key Sufi personalities, is still sorely needed. One of the major methodological challenges in treating al-Junayd's letters is the tendency towards a dominant literary nature which then turns the letter into a sort of a treatise on abstract Sufi matters. I argue that in spite of such a dominant literary nature and structure, Sufi letters can be a sufficient source in reconstructing certain elements of Sufis' social lives and communal engagements.

Al-Hakìm al-Tirmidhī (d. c. 295/908) is another source for the exchange of letters in early Sufism. Three letters that he wrote in response to two of his contemporaries are known to us. Two of these letters were addressed to Muhammad ibn al-Faḍl (d. 319/931) and are found in Sara Sviri's unpublished critical edition entitled Masă $i l$ wa-rasä $i l$, which is based on the Leipzig manuscript (No. 212). ${ }^{20}$ The third letter, published by Bernd Radtke, was addressed to Abū 'Uthmān al-Hīrī (d. 297/910), the renowned master of the malämatiyya group of Nishapur in al-Tirmidhī's days. ${ }^{21}$ In her chapter on al-Hakīm al-Tirmidhī and the malāmat̄̄ movement, Sara Sviri briefly refers to al-Tirmidhī's criticism of the concept of self-blame. This is the most fundamental doctrine of malämatiyya, as implied in one of the letters to Ibn al-Faḍl, and it hints at the significance of Sufi correspondence as a primary source in

19 See Su'ād al-Hakīm, Tāj al-'ārifiñ al-Junayd al-Baghdādì (Cairo: Dār al-Shurūq, 2004), 274-313 (where she published 14 letters and five introductory sections of letters taken from Kitāo al-Luma'). See also Ahmad Farīd al-Mizyadī, al-Imām al-Junayd sayyid al-tă ifatayn (Beirut: Dār al-Kutub al-'Ilmiyya, 2006), 334-60 (13 letters). For al-Junayd's letter see also Roger Deladrière, Junayd, Enseignement spirituel (Paris: Sindbad, 1983).

20 Sara Sviri, "The mystical psychology of al-Ḥakîm al-Tirmidhî”, PhD thesis (Tel-Aviv, 1979), 2: 77-86 (Arabic section).

21 See al-Hakīm al-Tirmidhī, Thalāthat mușannafāt li-l-Hakīm al-Tirmidhī: Kitāb sīrat al-awliyà', jawāb al-masầil allatī sa'alahu ahl Sarakhs 'anhā, jawāb kitāb min al-Rayy, Part 1 (Arabic texts), ed. Bernd Radtke (Beirut and Stuttgart: Franz Steiner, 1992), 190-2. 
reconstructing the dynamic and complex networks between the mystical circles in Khurāsān and Baghdad. ${ }^{22}$

Kitāb al-Luma of Abū Nașr al-Sarrāj is an important source of Sufi correspondence. Written in the course of the fourth/tenth century, it is the earliest source to include fragments of letters from a large group of figures; as well as point out the importance of correspondence between Sufi figures as a source of veiled, secret Sufi teachings, the concealment is an attempt to hide the material from non-Sufi eyes. On one occasion in the section devoted to Sufi terminology, particularly under his definition of the term ramz (symbol), al-Sarrāj refers very briefly to Sufi exchanges of correspondence: "The one who seeks to have an understanding of our masters' symbols, he should look for them in their exchanges of correspondence and letters; since their symbols are to be sought therein not in their compilations" (man arāda an yaqifa 'ala rumūz mashāyikhinā fa-l-yanz̧ur fì mukātabātihim wa-murāsalātihim fa-inna rumūzahum fìhā lā fì muṣannafätihim). ${ }^{23}$

Al-Sarrāj compiles a separate chapter in which he gathers a large number of Sufi letters in addition to the opening sections of letters whose originals are no longer available to us. This chapter appears as part of a long section that al-Sarrāj devotes to Sufis' mukātabāt, șudūr (introductions of letters), poems, prayers (da'awāt), and pieces of counsel (wașāyan) that Sufis used to send to each other. These topics demonstrate different aspects of the Sufi art of writing which al-Sarrāj chooses to locate directly after his thorough treatment of Sufi manners and before his discussion of practical Sufi piety; this practical piety includes both $\operatorname{sam}_{\bar{a}}$ (audition, the act of listening to a recitation of poetry or a song) and wajd (ecstatic state). Scholars of Arabic belles-lettres have noticed that, in the early history of Arabic literature, written messages were very often rhymed poems. In the Sufi realm, this notion helps explain why al-Sarrāj combines Sufi correspondence with poetry under the same section; by virtue of its structure and content, the implication is that the Sufi tradition of writing is a fundamental component of Sufi piety in general. Al-Sarrāj's belief in the role of Sufi writing is best manifested in his life as well. ${ }^{24}$ Pieces of correspondence in al-Luma' are not just included in the above-mentioned section but are scattered throughout the work. One example appears in the chapter on the concept of intimacy (uns), where a correspondence between an anonymous man and the Egyptian mystic Dhū al-Nūn al-Mișrī is mentioned. None of these occasions have as yet attracted much research.

22 See Sara Sviri, "Hakîm Tirmidhî and the Malâmatî Movement in Early Sufism", originally published in L. Lewisohn (ed.), The Heritage of Sufism (Oxford: Oneworld, 1999), and reproduced and republished by the author at: https://www.academia.edu/419941/ Hakim_TirmidhI_and_the_MalamatI_Movement_In_Early_Sufism (accessed 13/7/2019), 16.

23 Abū Nașr al-Sarrāj al-Ṭ̂̄sī, Kitāb al-Luma $\overline{\bar{c}} \overline{f_{\bar{l}}}$ al-tașawwuf, ed. Reynold Alleyne Nicholson (Leiden: Brill, 1914), 338.

24 Since Nicholson published his exhaustive edition of al-Sarrāj's work in 1914, which included a short, yet innovative, introduction, an English abstract of contents, a detailed index and a glossary, no comprehensive scholarly endeavour has been attempted to investigate this essential encyclopaedia of Sufism. There is a contradiction between the major influence this work has on almost every work on Sufism, and the lack of scholarly outputs that focus on it. 
Another Sufi author of the late fourth/tenth century, 'Abd al-Malik al-Khargūshī had a similar chapter on Sufi correspondence in his Tahdhīb al-asrār where he quotes short fragments of letters attributed to both Sufi and non-Sufi figures of early Islam. ${ }^{25}$ Unlike al-Sarrāj, al-Khargūshī’s chapter mixes references to Sufi letters with references to non-Sufi letters, probably as a means of emphasizing the integral position of Sufism within early medieval Muslim societies and culture. The data is, remarkably, dominated by a literary form of presentation with a clear tendency on the part of the author to convey proper Sufi ethics and morality. While this is also the general tendency in al-Sarrāj's work, we are still able to glean some features of the historical-social backgrounds of certain quoted fragments of letters.

In addition to the above-mentioned sources, there is an impressive body of correspondence and fragments of correspondence in the works of al-Ișfahānī's Hilyat al-awliyā', 'Abd Allāh Anșārī Haravī's Tabaqāt al-șūfiyya, Abū al-Qāsim al-Qushayrī's al-Risāla fì 'ilm al-tașawwuf, and Abū Khalaf al-Ṭabarī's Salwat al-'ärifin wa-uns al-mushtāqīn. In order to create a broader corpus, however, we need to search further for letters in manuscript archives and libraries. The collection of Şehit Ali Paşa (No. 1374), for instance, includes several letters ascribed to al-Junayd al-Baghdādī. One of the major difficulties is that most of the references to the term risāla in the bio-bibliographical indexes of Hājj̄i Khalīfa (kashf al-zunūn) and Fuat Sezgin (Geschichte des Arabischen Schriftums) relate, in fact, to long monographs. Titles that include risāla as private letters, kitāb ilā (a letter to), or jawāb ilā (a response letter to) should be searched for and added to the corpus. After creating the corpus, the process of identifying the bulk of letters pursuant to different criteria of both context and content as discussed under "conceptual-historical perspective" is needed.

Relevant textual material included in non-Sufi sources, in works of adab (belles-lettres), biographies and historiographies in particular, should be included. In these sources, short references to Sufi letters are occasionally provided. As well as being an occasional source for Sufi letters, non-Sufi works can also shed light on the historical contexts suggested in these letters. In al-Khatị b al-Baghdādī's (d. 463/1071) Ta' rīkh Baghdād, for instance, I found the following reference to Sumnūn ibn Hamza (d. c. 297/910): “A man wrote to Sumnūn asking him about his, that is Sumnūn's, situation after leaving his company. Sumnūn wrote to that man in response [...]". ${ }^{26}$ Shams al-Dīn al-Dhahabī's biography Siyar a lām al-nubalä' is an additional source for some of al-Junayd's correspondence with Yūsuf ibn al-Husayn in particular. ${ }^{27}$ Letters of this type should be evaluated with a view on their socio-religious context. In order to understand the personal and social background of al-Junayd's very long letter

25 See 'Abd al-Malik ibn Muhammad Ibrāhīm al-Naysābūī al-Khargūshī, Kitāb Tahdhīb al-asrār, ed. Bassāb Muhammad Bārūd (Abu Zabī: al-Majma' al-Thaqāfí, 1999), 533-41. See comments on this book by Christopher Melchert, "Khargūshī, Tahdhīb al-asrār", Bulletin of the School of Oriental and African Studies 73/1, 2010,29-44.

26 Abū Bakr Ahmad ibn 'Alī ibn Thābit al-Khațīb al-Baghdādī, Ta' rīkh madīnat al-salām wa-akhbār muhaddithīhā wa-dhikr qutțānihā al-'ulamā' min ghayr ahlihā wa-wāridīhā, ed. Bashshār 'Awwād Ma rūf (Beirut: Dār al-Gharb al-Islāmī, 2002), 10: 324.

27 See Shams al-Dīn Muhammd ibn Ahmad al-Dhahabī, Siyar a'lām al-nubalä’, ed. Shu ayb al-Arnā' ūt and others (Beirut: Mu' assasat al-Risāla, 1985), 14: 250-51. 
to 'Amr ibn 'Uthmān al-Makkī (d. 291/903-904 or 296/909), for instance, we must look for further data in non-Sufi sources: this will be discussed in detail below. These sources very frequently refer to letters in the form of "so and so addressed many letters to so and so" without quoting from the letter. Another interesting example is found in Ta' rīkh Baghdād. Al-Hallāj's (executed 310/922) son Aḥmad ibn al-Husayn ibn Manșūr is quoted as having described both the hostility of 'Amr al-Makki to his father and the efforts made by al-Makkī to send many denunciatory letters (yaktubu al-kutub) to the people of Khūzistān, where al-Hallāj lived at that time. ${ }^{28}$ Based on these instances, we can see how letters are a good source for ideas not included in the famous large-scaled Sufi manuals and magna opera.

If the famous Sufi manuals are designed to underline Sufi morals and to address the general concerns of the Sufi community, Sufi letters are sometimes meant to express more personal emotions and interests. Even when typical expressions recur in letters composed by the same Sufi figure, it is still worth examining particular characteristics that distinguish each letter regarding both the context and dynamics of interpersonal connections. While there are expressions common to all of al-Junayd's letters, for instance, each letter relates to one aspect of his diverse network of relationships. The section of this paper entitled "Conceptual-historical perspective" will examine this network through diverse structural discourses and rhetoric.

As with other Sufi materials, including anecdotes, sayings, and poetry, the authenticity of fragments of letters is not easily ascertained. More interesting than the question of authenticity are the reasons that led later Sufi authors to preserve these fragments. Al-Sarrāj, as I have already indicated, was the first to perceive the importance of these fragments in describing the nature of Sufism and the aspirations of its followers. On two occasions, he uses the expression "wajadtu fi kitāb" (lit. "I found in one kitāb") before quoting an anecdote about al-Junayd through the authority of Ja far al-Khuldī (d. 348/959), and before quoting one saying that appears in a kitāb of Abū Turāb al-Nakhshabī (d. 245/859). ${ }^{29}$ The phrase "wajadtu fì kitāb bi-khațtī..." appears very frequently in hadith literature, especially when the transmitter is eager to emphasize that he has consulted actual manuscripts in which the particular tradition and its chain of transmission are preserved. The word kitāb in such cases refers to a piece of paper, a notebook or a booklet but not to a regular book. ${ }^{30}$ If the reference is to a regular book, then the title of the book usually appears after the term kitāb. ${ }^{31}$ Al-Sarrāj's use of the phrase "I found in a kitāb" most likely relates

28 See al-Baghdādī, Ta’ rīkh Baghdād, 8: 690.

29 See al-Sarrāj, Kitāb al-Luma', 204 (reference to the anecdote about al-Junayd in a kitāb that al-Sarrāj saw with the handwritten manuscript of Ja far al-Khuldī); ibid., 205 (reference to a saying on wisdom (hikma) and its impact on Sufi novices that al-Sarrāj found in one kitāb of Abū Turāb al-Nakhshabī).

30 See, e.g., Jamāl al-Dīn Yūsuf ibn 'Abd al-Raḥmān al-Mizzī, Tuhfat al-ashrāf bi-ma' rifat al-atrāaf, ed. 'Abd al-Șamad Sharaf al-Dīn (Beirut: al-Maktab al-Islāmī and al-Dār al-Qayyima, 1983), 4: 85; Ibn Hajar al-'Asqalān̄̄, Ithāaf al-mahara bi-l-fawä id al-mubtakara min atrāf al-'ashara (Medina: Majma' al-Malik Fahd and Markaz Khidmat al-Sunna wa-l-Sīra, 1994), 6: 241.

31 See, e.g., Ibn Ḥajar al- 'Asqalānī, Lisān al-mīzān, ed. 'Abd al-Fattāḥ Abū Ghudda, 7: 124. 
to a piece of paper or a notebook; where he refers to the term kitāb alone, such as in his reference to one kitāb sent by al-Junayd to Mimshādh al-Dīnawarī (d. 299/ 911-2), the reference is to an original form of a letter. In such a case, al-Sarrāj relies on the authority of others who transmitted both the reference to the letter and its circumstances to him; al-Sarrāj indicates that he "heard Ahmad ibn 'Alī al-Karaj $\vec{\imath}$ " telling him that "al-Junayd addressed a letter to ...".32 On another occasion, al-Sarrāj indicates that "it was narrated about al-Shiblī that he addressed a letter to al-Junayd". 33

In cases where Sufi authors did not have such original versions in hand, they probably referred to consensual, orally transmitted versions. While referring to the response letter of Yūsuf ibn al-Husayn on al-Junayd's letter, Abū Nu aym al-Ișfahānī indicates that the transmitter "read the response letter". ${ }^{34}$ On another occasion, in his Hilyat al-awliy $\bar{a}$, al-Ișfahānī indicates that al-Junayd addressed a critical letter to his close companion, Ibrāhīm ibn Aḥmad al-Māristānī, concerning al-Māristānī's agreement with one of the muta'awwilīn, which most likely refers to Mu tazila and their exegesis tradition. ${ }^{35}$ Before presenting the text of the letter, al-Ișfahān̄ indicates that he had heard it from someone (akhbarana $\bar{a}$ bih $\bar{a}$ ) who transmitted it from another who transmitted it from someone who lived during al-Junayd's time. ${ }^{36}$

While it seems likely that some letters were transmitted orally, it could have been possible for some of these letters to have been handed down in writing among the close circle of the recipient's friends. It is likely that many of these letters were commonly conceived as personal or even secret and that they were not originally intended to be part of any public compilation. We know, for instance, that one of al-Junayd's secret letters fell into the hands of a group of people who could use it to threaten al-Junayd, as he himself indicates in another letter that he addressed to Abū Bakr al-Kisā' $\overline{1}$ al-Dīnawarīi. ${ }^{37}$

On many occasions when recipients shared letters with their coteries, some of their companions copied parts of these letters, or at least the introductory parts,

32 Al-Sarrāj, Kitāb al-Luma', 232-3.

33 Al-Sarrāj, Kitāb al-Luma , 233. Cf. the reference to another letter to which al-Sarrāj refers through the authority of Abū 'Alī ibn Abī Khālid, ibid., 234.

34 Abū Nu'aym al-Ișfahānī, Hilyat al-awliyà wa-țabaqāt al-aşfiyà' (Cairo: Maktabat al-Khānjī and Dār al-Fikr, 1996), 10: 240. It is interesting to note that Abū 'Abd al-Raḥmān al-Sulamī (d. 412/1021) in his Tabaqāt al-șüfiyya quotes the same textual piece but with variations and not as a letter; see Abū 'Abd al-Rahmān al-Sulamī, Țabaqāt al-șüfiyya, ed. Mușțafā 'Abd al-Qādir 'Ațā (Beirut: Dār al-Kutub al-'Ilmiyya, 1998), 153.

35 See al-Iṣfahānī, Hilyat al-awliya $\bar{a}^{\prime}, 10: 331-2$. The term ta' wìl (interpretation) signifies different meanings. While during the first two centuries of Islam this term was a synonym of tafsì $r$, by the third/ninth century many lexicographers and philologists started differentiating between the two, stating that $t a^{\prime}$ will, more than tafsìr, has to do with understanding, reasoning and interpretation; see, e.g., Kifayat Ullah, al-Kashshäf: al-Zamakhshari $\vec{s}$ Mu'tazilite Exegesis of the Qur'än (Berlin and Boston: Walter de Gruyter, 2017), 58-62.

36 al-Ișfahānī, Hilyat al-awliy $\bar{a}^{\prime}, 10: 332$. Another part of this letter appears in the biography of al-Junayd (see ibid., 10: 276). Su'ād al-Hakīm publishes the two parts preserved by al-Ișfahānī into one long letter in al-Ḥakīm, Tāj al-'ārifín, 290-2.

37 See al-Sarrāj, Kitāb al-Luma', 240. 
thereby creating their own "șürat kitāb" (lit. an image or copy of a letter). This term is very common in Classical Arabic works of $a d a b$, biographies, and historiographies. Physically, these copies were handwritten on paper or skin patches (sing. ruq $a$ ) and passed among acquaintances, authors, and scholars. ${ }^{38}$ It would be possible to assume, furthermore, that there were also occasions on which certain short messages were orally transmitted. This assumption fits with the idea that mutual inquiries (masāil $i l)$ and answers (ajwiba) on Sufi terms and conditions played a fundamental role in early Sufi tradition. Many of these inquiries and answers were a form of orally transmitted letters. ${ }^{39}$ What began as an oral message, however, was later documented in writing through different forms of transmission when acquaintances of both the sender or the recipient had interest in the content. While this process of transmission succeeded in preserving a huge number of letters, we should bear in mind that this occurred to a greater extent with administrative letters and letters with typical literary values. Personal letters, on the other hand, were easily missed and ignored due to the lack of interest in what was seen as private "business" between relatives or companions. On one occasion in 'Abd al-Karīm ibn Muhammad al-Rāfi 'ì al-Qazwīn̄’s (d. 623/1226) historiography, he states that he himself saw a handwritten document of the $q \bar{a} d \bar{l}$ 'Abd al-Malik ibn al-Mu'āfā in which he, the $q \bar{a} d \bar{l}$, quotes a verse taken from the introductory part of a letter (șadr kitāb) addressed by Abū Țāhir al-Ja farī, the honourable personality of Qazwīn, to his grandfather Muhammad. ${ }^{40}$ On another occasion, al-Răfi ' $\overline{1}$ indicates that he saw another person in a high administrative position in Qazwin writing some verses at the top of a letter addressed to one of his friends. After quoting these verses, al-Rāfi' $\overline{1}$ tells a story about Ahmmad al-Ghazālī (d. 517/1123 or 520/1126), the young brother of Abū Hāmid al-Ghazālī (d. 505/1111), which appeared in the main body of that letter (khilāl al-kitāb). ${ }^{41}$

It is important to remember that Sufi letters are rarely just personal or private documents. They usually take the form of public literary epistles due to the large space they devote to discussions of Sufi conduct. Personal and interpersonal features, however, can still be gleaned; but these are not always easy to see and a cross-check with other types of sources is required. Comparing Sufi letters with private and official letters that belong to general medieval Islamic epistolography ${ }^{42}$ demonstrates an important part of what was meant by

38 See al-Sarrāj, Kitāb al-Luma', 204. Al-Sarrāj indicates here that he found an anecdote telling of al-Junayd in a kitāb that he saw, and that it includes a handwritten script of Ja far al-Khuldī. It is not clear whether the use of the word kitāb here signifies a letter or a piece of paper. This is also the case on another occasion on which al-Sarrāj indicates that he found (which means "saw") in one kitāb of Abū Turāb al-Nakhshabī a saying on wisdom (hikma) and its impact on Sufi novices: "wajadtu fi kitāb Abī Turāb al-Nakhshab $\vec{\imath}$ ' (ibid., 205).

39 See Abdel-Kader, Life, Personality and Writings of al-Junayd, Introduction, 53.

40 See 'Abd al-Karīm ibn Muhammad al-Rāfi' ì al-Qazwīn̄̄, al-Tadwìn fì akhbār Qazwìn, ed. 'Azīz Allāh al-'Uțāridī (Beirut: Dār al-Kutub al-'Ilmiyya, 1987), 1: 199.

41 See al-Qazwīn̄i, al-Tadwīn, 4: 98.

42 Epistolography is the art of writing letters. This is an ancient art, as proved by the large quantities of authentic papyrus letters discovered in Egypt covering the period between 
überreste, and this is useful for two major reasons. It helps situate Sufi letters into their broader religious, social and historical contexts as well as delineate specific structural attributes that distinguish Sufi letters as a unique category of Islamic epistolographical literature. In Sufi letters that I have been able to access, abstract literary contents concerning Sufi conduct and general manners and beliefs still occupy a prominent place; however, many of the letters go beyond the displays of Sufi manners to include references to particular circumstances and events. Having said this, we are still unable to know with any confidence whether senders of early Sufi letters intended exclusively to address particular real-life situations or whether they were taking advantage of such situations to express appropriate conduct for future generations of Sufis. I would argue that, occasionally, a letter could have been a response to a real set of circumstances, which was then amended to reflect general Sufi conduct, thereby giving the letter more timeless value. The following example relates to Bishr ibn al-Hārith (d. 227/841) and sheds light on two correlated issues: the first is the nature of relationships between historical context and theoretical presentation of morals in one Sufi letter; and the second is the problematic issue of authenticity, which questions the circumstances that surrounded the composition and address for each letter. This question is raised very often when the given letter is shaped in a way that combines a common structure of letterwriting in general with the actual historical event that motivated the writing of the letter. Some Sufi letters are likely to be shaped differently without any connection to a particular event. These follow the general format of "so-and-so wrote a letter to so-and-so ...".

On one occasion in Kitāb al-Luma', al-Sarrāj mentions that Bishr ibn al-Hārith (known as Bishr al-Hāfí, "Bishr the Barefoot") used to work in textile spinning wheels (wa-kāna Bishr ya malu fì al-maghāzil) with one of his sisters. He earned enough from that work until one of his Sufi contemporaries, Ishạa al-Maghāzilī (d. 282/896), ${ }^{43}$ sent him a letter accusing him of abandoning the

the third century BCE far into the Christian era (see Francis Xavier J. Exler, A Study in Greek Epistolography: The Form of the Ancient Greek Letter, a dissertation submitted to the Faculty of Letters of the Catholic University of America in partial fulfilment of the requirements for the degree of Doctor of Philosophy (Eugene, Oregon: Wipf and Stock Publishers, 2003), 15-22). Early Christian letters have been proven to reflect different degrees of interaction with ancient Jewish letters (see, e.g., Lutz Doering, Ancient Jewish Letters and the Beginnings of Christian Epistolography (Tübingen: Mohr Siebeck, 2012), 4). The art of letters marked pre-modern Islamic society, and a large number of letters allegedly exchanged during the early Islamic period are provided by works of belles-lettres as historiographies. Adrian Gully indicates that the term "șinä at al-tarassul" (the craft of letter-writing) became the generic term for epistolography" in Arabic culture (Gully, The Culture of Letter-Writing, 2). Scholarship of Islamic letter-writing tradition benefits from general stylistic studies of papyri documents as well as studies of the Cairo Geniza such as that of Werner Diem who focuses on private letters in Egypt in the period between the tenth and sixteenth centuries (see Werner Diem, Arabische Privatbriefe des 9. bis 15. Jahrhunderts aus der Österreichischen Nationalbibliothek in Wien (Wiesbaden: Harrassowitz, 1996)).

43 His name, according to al-Dhahabī, is Badr or Aḥmad, Abū Bakr ibn al-Mundhir al-Maghāzilī al-Baghdādī, a companion of Ahmad ibn Hanbal (see al-Dhahab̄î, Siyar a' lām al-nubalä', 13: 490-1. 
pure devotional life in the search for worldly profits. The passage quoted by al-Sarrāj is: "I have heard that you have become satisfied with working in spinning wheels for your subsistence. With whom will you be able to seek refuge if God deprives you of your senses of hearing and seeing?" We do not know if this was a sort of a completed telegram-style letter or just a single passage taken from a longer original letter. What we do know based on what al-Sarrāj narrates is that the letter left a deep impact on Bishr and caused him to abandon completely the profession he was pursuing with his sister. ${ }^{44}$

On the assumption that this short fragment was taken from a longer authentic letter, we might suggest that the original letter included further passages of a general literary nature celebrating the high Sufi ethos of absolute dependence on God (tawakkul) and a full devotional life; however, we should keep in mind that this does not change the main focus of the original letter which is to castigate a specific Sufi figure for a specific controversial behaviour at one specific point in time. It is still interesting to note that the way this letter is introduced to Kitāb al-Luma' presupposes that al-Sarrāj probably intended to show Bishr's approach towards the dilemma of working for one's subsistence or choosing to commit oneself totally to tawakkul. It is also possible that al-Sarrāj sought to emphasize the idea that Bishr changed his approach on this subject and finally abandoned working for his subsistence. The brevity of this letter does not allow further investigation into the questions of how and to what extent moral discussions were able to set the tone of the letter originally written in response to a certain event or under the influence of a specific situation. General moral discussions are usually common in literary letters, that is, in rasä $i l$ as treatises or monographs. This investigation is possible with a longer example letter and will be discussed in the following section.

\section{Conceptual-historical perspective}

In this section, I will discuss questions of content, as well as different expressive forms and styles relating to the changing conditions and historical events in certain relevant letters. This examination will also involve analysing rhetoric and forms of argumentation, self-justification and self-representation of the senders and their use of frequent structural features, metaphors and symbols. It will focus on structures used by either different senders or by the same sender whether writing to different addressees or for different pragmatic purposes.

Based on content, conditions, and historical events, the bulk of Sufi letters will be identified in different ways. One method will be to distinguish between general letters addressed either to an anonymous individual or to a group from letters whose addressees are specific. This is, for instance, the case in one of Abu Hafs al-Suhrawardī's letters to "one of the Sufis", which takes the form of a piece of counsel (wasiyya ilā ahad al-fuqară') and revolves around general codes of behaviour and good manners each Sufi aspirant needs to adopt. ${ }^{45}$

44 Al-Sarrāj, Kitāb al-Luma', 195.

45 This text was first mentioned by Brockelmann and Ritter; see H. Ritter, "Philologika IX: Die Vier Suhrawardī”, Der Islam 25, 1939, 45, no. 56; Carl Brockelmann, Geschichte der arabischen Litteratur (GAL) (Leiden: Brill, 1943), I, 441, no. 19; Brockelmann, 
One interesting example of letters addressed to a general group is the surviving part of the letter of 'Amr ibn 'Uthmān al-Makkī to the group of the Sufis of Baghdad who are known in the early history of Sufism as süfiyya. Al-Sarrāj tells us that when this letter arrived, it was read in the presence of al-Junayd, al-Shiblī (d. 946/334), and Abū Muhammad al-Jurayrī (d. 312/924), who were among the most prominent members of the süfiyya group. ${ }^{46}$

If the rhetoric of the letters is considered, then we should differentiate between letters whose style is purely poetic, letters which are written metaphorically, and letters which quote the sayings of other Sufis. This method of classification is not always clear-cut, and crossovers do occur. In his famous letter to 'Amr ibn 'Utmān al-Makkī, al-Junayd adopts a metaphorical, narrative style by relaying the textual dialogue between a learned man ( $\bar{a} l i m$ ) and a wise man (hakim). In this dialogue, the wise man strives to convince the learned man to replace all the earthly considerations, such as greed, social fame, or leadership, that underpin the learned man's religious science with an exalted type of inner science. ${ }^{47}$ The learned man throughout this long dialogue is portrayed as submissive and slavish. He repeatedly confesses that lower earthly benefits motivate his search for religious knowledge. The voice of the wise man, on the contrary, is dominant and very assertive. In one passage the learned man is quoted saying:

O gentle and merciful teacher, instructor of good counsel and of wisdom, your description of these people has made my heart worry and you have filled my breast with fear. By your description, I know my status and my rank and I fear that my knowledge which I now have may be beyond my endurance, because of what you have made clear about the extremity of my incompetence and the persistence of my being left behind. ${ }^{48}$

A short passage that appears in the biographical work of Shams al-Dīn al-Dhahabī sheds an interesting light on this letter:

'Amr ibn 'Uthmān al-Makkī was one of the honourable masters of jurisprudence, and when he was appointed to the position of $q \bar{a} d \bar{\imath}$ of Jeddah, al-Junayd no longer associated with him. ${ }^{49}$

On another occasion in his Tārìkh al-Islām, al-Dhahabī indicates that when 'Amr al-Makkī came to Baghdad, undertook the position of qāạ in Jeddah

GAL, Suppl I (Leiden: Brill, 1937), 790, no. 18. I have two Mss of this text, the first is that of Biblioteka Jagiellońska (Spr. 769, 3991, fols 65a-68b), and the other is that of the Yahuda Collection (Tașawwuf, 3/179, fols 4b-5a).

46 Al-Sarrāj, Kitāb al-Luma', 233.

47 See this letter in al-Junayd, Rasä'il al-Junayd, in Abdel-Kader, Life, Personality and Writings of al-Junayd, Arabic text, 7-26.

48 Al-Junayd, Rasäil al-Junayd, Arabic text, 24. The English translation is from Abdel-Kader, Life, Personality and Writings of al-Junayd, English part, 144.

49 Al-Dhahabī, Siyar a 'àm al-nuabalä’ , 14: 58. The English translation is mine. 
and became ill, al-Junayd did not visit him during his sickness. ${ }^{50}$ If we add this notion to the structural and thematic components of the letter itself, we come to the conclusion that al-Junayd was critical of the jurists of his day, and that this attitude took form in a poignant letter whose actual effects on the addressee are unknown. This is one example of the rich array of data that Sufi letters can present particularly once they are cross-checked with textual evidence provided by non-Sufi sources.

I have already noted that al-Sarrāj was the first author to dedicate a separate chapter in his work to Sufi letters and correspondence. Only a few Sufi authors who lived after him do that as well. In the majority of cases, Sufi authors choose to include references to letters and to quote fragments from earlier letters in different discussions throughout their work. The choice by a later author to mention a particular letter was generally based on one key concept emphasized in that letter which helps the author prove the correctness of his worldview. ${ }^{51}$ By its very nature, this method of using letters contributes to strengthening the literary aspects of these texts over any historical-actual aspects; it disconnects the letters from their original contexts and makes it very difficult for us as researchers to reconstruct the circumstances of writing and generating the original letters.

Al-Sarrāj was unique in the ways he chose both to preserve Sufi letters and to use them in his work. Our survey of the relevant material in Kitäb al-Luma leaves no doubt that al-Sarrāj was conscious of the fundamental importance of these texts as one of the pillars of Sufis' communal life both from early Sufi history and continuing until his own time. It is surprising, however, that authors of Sufi manuals who lived after him and frequently cited his work did not share his interest in Sufi exchanges of letters; this needs to be the subject of further research.

One of the early Sufi letters that deserves special mention is al-Junayd's letter to Yūsuf ibn al-Husayn al-Rāzī, a distinguished mystic of Rayy of that period. Different sources state that this was one of a series of letters between these two figures. Abdel-Kader, although he refers in some detail to the relationship between al-Junayd and Yūsuf ibn al-Husayn, does not relate to the content of their correspondence, its rhetoric, or the way in which the structure might suggest some aspects of the relationships between them. It is highly likely that it was al-Junayd who initiated this correspondence, as evidenced by the statement "bada' tuka bi-kitāb $\vec{\imath}$ " (I began my letter to you) at the end of his letter, ${ }^{52}$ and that Yūsuf ibn al-Husayn's letter, or even several letters to al-Junayd, came in response. Al-Junayd opens his letter with a long paragraph whose rhetoric relies on the intensive use of verbal sentences in the past tense. This writing style was very common in Classical Arabic letters and was used by the author to invoke divine favour on behalf of their addressees. At first sight, al-Junayd's opening

50 See Shams al-Dīn al-Dhahab̄i, Tārīkh al-islām wa-wafayāt al-mashāhīr wa-l-a' lām, ed. Bashshār Ma rūf (Beirut: Dār al-Gharb al-Islāmī, 2003), 6: 990.

51 One example is the letter of Abū al-Khayr al-Tīnānī to Ja far al-Khuldī as referred to by al-Qushayrī in: Abū al-Qāsim 'Abd al-Karīm ibn Hawāzin al-Qushayrī, al-Risāla al-qushayriyya (Cairo: al-Bābī al-Halabīi, 1940), 146. See the detailed reference to this letter hereinafter.

52 al-Junayd, Rasä'il al-Junayd, Arabic text, 30. 
leaves the impression that he praises Ibn al-Husayn's high spiritual rank as one whom God chooses to grant walāya, an elevated position of closeness and friendship. ${ }^{53}$ However, on deeper analysis, what seems like praise presented in the form of positive invocations, turns into a description of how far Ibn al-Husayn needs to travel spiritually in order to attain a high spiritual rank. The first sentences in the opening reads:

\section{kashafa al-Haqqu laka 'an ḥaqīqat anbā' ihi, wa-tawallāka bi-'ażìmi min- anihi wa-ālà ihi, wa-tadammanaka fì dammihi iyyāka ilā sawābigh na'mä'ihi, wa-jarat 'alayka bi-raf ihi laka ilayhi wa-i'la'ihi, fa-kunta bi-haythu lā takūnu al-aghyāru laka ilayhi sababan, bal takūnu bi-mā yūjidu bihi minka muntasiban.}

May God reveal to you the true nature of His revelation, and grant you the greatness of His favour and graciousness. May He contain you by embracing you yourself in the fullness of His beneficence which, when they reach you, are the grace of His raising you and exalting you. Then will you be where no other is a mediator between you and Him, but you will be in a relationship with God based on that which God has given you. ${ }^{54}$

Following this graceful and muted opening, al-Junayd's tone becomes more direct, negative, and obvious. He describes very unfavourably the reality that he has seen with the existence of many pretenders who lack sincerity and truthfulness while looking for earthly benefits in their learning and teaching involvement in circles of 'ilm (religious science). Afterwards, al-Junayd turns to address Ibn al-Husayn, without stating his name or title, and while acknowledging his role as a guide to people on the path of truthfulness, he urges him to strengthen his authority over his disciples: "Turn to your disciples and give them your full attention, face them and concentrate on them [...] be with them both by night and by day and give them that special cognisance of your experience". ${ }^{55}$ The latter part of the letter implies that al-Junayd felt that his addressee is expected to feel insulted by the powerful and authoritative tone of this letter, and that is why he writes: "Now I began my letter to you with a view to establishing our closer contact, seeking your attention and your good graces and hoping that it would cause you to write back to me [...] and I should like to apologize in advance in the event of your not accepting it". Al-Junayd

53 On the term walāya and the position of walı (pl. awliya $\bar{a}^{\prime}$ ) in early Sufism, see Bernd Radtke, "The concept of wilāya in early Sufism", in Leonard Lewisohn (ed.), Persian Sufism: From the Beginning to Rumi (London: Khaniqahi Nimatullahi Publications, 1994), 483-96; Radtke, "Walī", Encyclopaedia of Islam, second edition, part 1, consulted online on 15 July 2019. On walāya in the teachings of al-Junayd, see Ahmet Karamustafa, "Walāya according to al-Junayd (d. 298/910)", in Todd Lawson (ed.), Reason and Inspiration in Islam: Theology, Philosophy and Mysticism in Muslim Thought, Essays in Honour of Hermann Landolt (London: I.B. Tauris, 2005), 64-70.

54 The translation is from Abdel-Kader, Life, Personality and Writings of al-Junayd, English part, 147.

55 Abdel-Kader, Life, Personality and Writings of al-Junayd, English part, 150 
explicitly urges Ibn al-Husayn to be cautious with his contemporaries and advises him to speak only after he is sure that he knows his listeners. ${ }^{56}$

Before examining the response letters of ibn al-Husayn, a brief remark concerning the historical and religious contexts of this exchange of letters should be noted. Recent scholarship on the formative period of Sufism has shown that al-Junayd and his close circle of Baghdadi Sufis succeeded during the course of the third/ninth century in establishing a strong and authoritative institution of Sufi piety based on a group of doctrines and renunciatory practices. ${ }^{57}$ Representatives of this group began to spread this type of piety to the eastern parts of the Muslim world in an attempt to ensure the supremacy of their own image of Sufism over all other images and forms that then existed. Baghdadi Sufis, with al-Junayd as their most influential leader, aspired to prove that their perception of tașawwuf was the best one. Analysing al-Junayd's letters, and more specifically his letter to Ibn al-Husayn of Rayy, through the prism of the debate between the malāmatì trend and the Baghdādī trend, one can see that al-Junayd intended to maintain and strengthen the religious authority of Iraqi piety over the Sufis of the East; the above-mentioned quotations and the arrogant tone implied in its rhetoric and phrasing leave a strong impression that this was the case. In one part of the letter, al-Junayd writes: "My brother, it was not my desire to draw your attention to a privilege and a duty which you neglect, nor to any suspected deficiency [...] but God says: Teach for instruction is of avail to those that believe". 58

As for Ibn al-Husayn's response letter, or set of letters, Abū Nu'aym al-Ișfahānī preserves a very short passage of what was commonly identified by al-Iṣfahān̄ and later authors as Ibn al-Husayn's jawāb (response) to al-Junayd. It is likely that this passage was taken from a long-missing letter in which Ibn al-Husayn defends himself against accusations of heresy addressed to him by some jurists of Rayy, along with a critical approach of the Baghdadi Sufis whom al-Junayd leads and represents. Al-Qushayrī indicates that in this letter to al-Junayd, Ibn al-Husayn prays to God that al-Junayd keep himself from tasting his "lower soul's flavour", since, by tasting his lower soul's flavour, he "will not obtain any goodness forever": "Iā adhāqaka Allāhu ta'ma nafsika, fa-innaka in dhuqtahā lam tadhuq ba'dahā khayan Abadan". 59 This statement, which implies a response to the arrogant tone in al-Junayd's original letter, appears in what seems to be a missing response letter of Yūsuf ibn al-Husayn in the Șehid Ali Pașa manuscript. ${ }^{60}$ This is one of two response letters that were, allegedly and most probably, addressed by Ibn al-Husayn. They are preserved in the Süleymaniye Yazma Eser Kütüphanesi in Istanbul. Though there is no reference to the recipient's name in the main body of both letters, a careful reading strengthens the assumption that the sender

56 Abdel-Kader, Life, Personality and Writings of al-Junayd, English part, 151.

57 See the pioneering work of Ahmet Karamustafa, Sufism: The Formative Period (Berkeley and Los Angeles: University of California Press, 2007), 1-7, 19-26

58 Qur'ān, Sūra 18, verse 28. Abdel-Kader, Life, Personality and Writings of al-Junayd, English part, 151.

59 Al-Qushayrī, al-Risāla al-qushayriyya, 24.

60 See MS Șehid Ali Pașa, 1374, fol. 2b. 
addressed the letters to one charismatic master whose initial critical letter was hurtful. As I have already mentioned, the first modern scholar to refer to these two letters was Muhammad Mușțafā in his 1978 edition. Muștafā, like Abdel-Kader before him, does not provide any discussion of the texts that he edits. More recently, Jamāl Rajab Sīdbī republished al-Junayd's Rasä il, including both his letters and short treatises on tawhìd and other Sufi issues based on a manuscript of Ma'had al-Makhțūtāt al-'Arabiyya in Cairo. Appended to the above-mentioned letter of al-Junayd to Ibn al-Husayn, Sīdbī published an additional part that does not appear in Abdel-Kader's edition. ${ }^{61}$ This part deals with how different types of Sufis view intoxication ( $s u k r)$ and it has little relevance to the topic and rhetoric of al-Junayd's letter; this leads us to doubt its authenticity. Later in his edition, Sīdbī published another letter which he maintains was addressed by al-Junayd to someone called Yūsuf ibn Yahyā, thus causing confusion between two separate figures of Rayy who had both exchanged letters with al-Junayd: Yahyā ibn Mu'ādh and Yūsuf ibn al-Husayn. ${ }^{62}$ This was the response letter addressed by Ibn al-Husayn to al-Junayd ${ }^{63}$ and this view is shared by Muștafā. In Sufism and Early Islamic Piety (pp. 129-34), I relied on the Şehit Ali Paşa manuscript to examine thoroughly the structural and thematic features of these two letters while providing English translations for some parts of them. The opening paragraph is of particular interest. The author, after praising his addressee, clearly indicates that the latter has given him a blow and caused him pain (darabta fa-awja ta). He compares his addressee to the prophets who chose leniency while guiding their people down the path of truth and belief; nonetheless, he asserts that, like all prophets, his addressee is not able to guide anyone alone since no one other than God is capable of guiding people. The different rhetorical strategies used by the author to establish this message, in plain terms on some occasions and metaphorically on others, help him refrain from turning his letter into an explicit trigger for personal dispute. At one point in this letter, for instance, the author indicates that he has benefitted from the addressee's previous letters to him in choosing the style and language for his own letter. ${ }^{64}$ This letter provides many contextual-historical values. By the end of this letter, the author relates that some renunciants (zuhhād), who had visited the addressee from the author's region, returned home and asked the author to "scale up" (istazādūnä); this could be interpreted as their asking him to commit himself to more devotional rituals as is now their commitment. The second response letter is shorter and its style is similar to the first. Some of its passages were quoted by both Abū 'Abd al-Raḥmān al-Sulamī (not as a letter but as a general saying) and al-Ișfahānī. ${ }^{65}$ The general tone suggests a sort of a controversy that the author had with the addressee in relation to the passionate

61 See al-Junayd, Rasāil al-Junayd: Awwal 'amal yajma' kull rasā'il al-imām al-Junayd wa-aqwālahu al-ma' thūra, ed. Jamāl Rajab Sīdbī (Damascus: Dār Iqra', 2005), 178-9.

62 al-Junayd, Rasä il al-Junayd, 191-4.

63 See al-Junayd, Rasảil wa-rudūd, in Tāj al-'ārifin: Dirāsāt wa-nușūs manshūra wa-ghayr manshūra, ed. Muhammad Mușțafā (Cairo: Dār al-Ṭibā'a al-Muhammadiyya, 1987), $338-51$.

64 See al-Junayd, Rasä̀il wa-rudūd, 342.

65 See al-Ișfahānī, Hilyat al-awliya $\bar{a}^{\prime}$ 10: 240; al-Sulamī, Tabaqāt al-șūfiyya, 153. 
language that he, the author himself, chose to express his love and intoxication: "You asked me to avoid writing to you using irrational language (hadhayān) as well as to avoid the talk style of the insane (kalām al-ma 'tūh)". ${ }^{66}$

I have already referred to the question of why the majority of personal letters in Sufi domains did not come to us in their original handwritten forms, and how some of these letters were known to other contemporaries who helped transmit passages of them at a later date to authors of collections and Sufi compendia. According to one reference that appears in al-Ișfahānī's Hilyat al-awliya $\vec{a}$, a man of Rayy, who was a well-known munshid (reciter of poetry), ${ }^{67}$ indicates that, when the letter of Ibn al-Husayn reached al-Junayd, he, this man, wished that he could see it due to its charm. It is not clear how this man knew about the charms of Ibn al-Husayn's writing style and what exactly is intended by charm. This man goes on to tell that he left Baghdad for Rayy in order to meet the author of the letter. When this man began to recite poetry, as Ibn al-Husayn requested, the latter began to cry and admitted that the people of Rayy correctly accused him of heresy since reciting the Quran did not cause him similarly to cry! ${ }^{68}$

Immediately after this reference, al-Ișfahānī quotes one of al-Junayd's companions, Abū al-Hasan 'Alī ibn Hārūn, as having said: "I read in the response letter of Yūsuf ibn al-Husayn to al-Junayd [...]". What follows is a passage taken from the original second response letter of Ibn al-Husayn ${ }^{69}$ and is additional proof for the argument that Sufi letters were accessible to the close circles of both senders and addressees. The way many of these letters were conceived as functional texts might have caused the loss of the originals; however, the close circles of senders and addressees helped preserve certain traces of contents in which these circles were interested so that they succeeded in remembering and transmitting.

In addition to Ibn al-Husayn, many other personalities corresponded with al-Junayd. What we have as evidence is restricted to brief references to their names and the general nature of their letters, without quoted texts. On one occasion in Ibn al-Jawzī's biographical work Șifat al-safwa, the author indicates that 'Alī ibn Sahl was one of the best men at using the symbolic style (min ahsan al-nās ishäratan), and that he used to exchange letters with al-Junayd while al-Junayd praised him and likened his language to that of angels. ${ }^{70}$

Ibn al-Husayn's letters provide excellent examples of how Sufi letters enable us to reconstruct possible conflicts and tense encounters in the daily lives of early Sufis. Sometimes, such encounters are implied in plain brotherly letters,

al-Junayd, Rasä' il wa-rudūd, 349-50. For a detailed discussion of these two response letters, see Salamah-Qudsi, Sufism and Early Islamic Piety, 130-34.

67 While the name of this man in Ișfahān̄̄'s text is Yatīmik al-Rāzī (see al-Iṣfahānī, Hilyat al-awliya ${ }^{\prime}, 10: 240$ ), it appears in Ta' rīkh baghdād as Abū al-Husayn al-Darrāj (see al-Baghdādī, Ta' rìkh baghdād, 14: 317).

68 al-Ișfahān̄i, Hilyat al-awliyā', 10: 240.

69 al-Ișfahānī, Hilyat al-awliyā', 10: 240-41.

70 Ibn al-Jawzī, Sifat al-șafwa, ed. Ibrāhīm Ramaḍān and Sa '̄id al-Lahhāàm (Beirut: Dār al-Kutub al-'Ilmiyya, 2006), 4: 80. 
for example the letter of Abū al-Khayr al-Tīnātī ${ }^{71}$ to Ja far al-Khuldī, in which al-Tīnātī blames al-Khuldī for not taking responsibility for the ignorance of his followers. ${ }^{72}$ Again, the letter was addressed in response to a set of real circumstances, while any existing additional parts dealing with general Sufi conduct have been appended to give the letter more timeless value. In other cases, however, such general and timeless content serve as a fundamental part of the Sufi letter, while the real historical content is hidden. This is the case in al-Junayd's letter, or probably several letters, to the honourable preacher and mystic of Rayy, Yahyā ibn Mu'ādh al-Rāzī (d. 258/872). Fragments of this letter are preserved in the Şehit Ali Paşa manuscript, ${ }^{73}$ while others appear in Kitāb al-Luma' ${ }^{74}$ The reader notices al-Junayd's clear attempt to show his generous knowledge of Sufi terminology and his exceptional writing talent. The literary nature which is dominant in this letter motivates us to ask why al-Junayd chose this general, less historical, rhetoric for one letter while relying on some historical-contextual features in another. Unfortunately, this question remains unanswered. In both cases, however, it is clear that the direct trigger for creating the letters was a real set of events in a certain context. Even when the risāla served as a small book sent by its author to deliver certain teachings and ideas, this was motivated by actual situations and to fulfil specific needs in the living reality of both sender and addressee.

Al-Junayd was not the only Sufi leader who sent letters that contain rebuke and criticism. Hasty and brief references to many other figures who addressed short messages to others also appear in the early sources. These messages usually take the form of telegram-messages that include very few sentences and whose focus is on the sender's critique of certain behaviours of the addressee; this is expressed through a generally moralistic tone without any direct reference to the addressee's identity. One example is the aforementioned letter addressed by Abū al-Khayr al-Tīnātī to Ja far al-Khuldī. In addition to the reference to al-Sarrāj, the letter appears in al-Qushayrī Risāla as follows:

The responsibility for Sufis' [lit. poor's!] lack of knowledge is on you; since you were so wrapped up in yourselves and forgot to guide them; they remained uneducated. ${ }^{75}$

On certain occasions, the texts of letters, which were primarily dominated by moralistic issues and discussions, leave the impression that those letters were delivered orally. Al-Qushayrī indicates that Yahyā ibn Mu'ādh of Rayy wrote (kataba) to Abū Yazīd al-Bastạmī telling him that "here is someone who has

71 Ibn Kathīr states that al-Tīnātī was an originally Arab renunciant who lived in a village called Tīnāt in the region of Anțākia and was known by the title al-aqta", "the amputee", since his arm was cut after he broke a word that he undertook with God and, later on, was arrested by mistake with a group of thieves in the desert where he used to spend his devotional retreats. Al-Tīnānī died in 343/955. (See his biography in Abū al-Fidā' Ibn Kathīr, al-Bidāya wa-l-nihāya, ed. 'Abd Allāh al-Turkī (al-Jīzah: Dār Hajr, 1998) 15: 221.)

72 al-Sarrāj, Kitāb al-Luma', 236.

73 Şehit Ali Paşa MS, $3 b$.

74 al-Sarrāj, Kitāb al-Luma', 358.

75 al-Qushayrī, al-Risāla al-qushayriyya, 146. The English translation is mine. 
drunk from the goblet of God's eternal love so that he can never be thirsty again ever". It was said that al-Bastāimī wrote to Yahyā in response: "I was astonished by the weakness of your state! Here is someone who drinks the seas of the universe and he still opens his mouth seeking much more [water!]". ${ }^{76}$ It seems probable that the verb kataba, here as on other similar occasions, was used in the sense of "he sent an oral message". On another occasion of al-Risāla al-qushayriyya, a reference was made to Abū 'Uthmān al-Hīīī, who "wrote to Muhammad ibn al-Faḍl asking him: what is the sign of misery?"77 Sufi literature is fraught with notions of this kind. References to different forms of contact between early Sufi personalities (exchanges of letters, travelling, companionship, suhbba, etc.) were very often designed to emphasize particular religious aspects of these personalities or to help authors defend certain earlier personalities who were targets of non-Sufis' criticism. Assuming that the contact between al-Hīrī and Muhammad ibn al-Faḍl was real, the reference to the letter might preferably be understood as an oral inquiry that al-Hīrī addressed to Ibn al-Faḍl by means of a direct encounter or through a messenger. ${ }^{78}$ From another perspective, it is possible that the entire story was fabricated by later authors to establish the alleged close relationship between these two figures and to use this relationship to defend Muhammad ibn al-Faḍl who was accused by the jurists of Balkh of generating illicit innovations in religion (mubtadi $).{ }^{79}$

76 al-Qushayrī, al-Risāla al-qushayriyya, 160.

77 al-Qushayrī, al-Risāla al-qushayriyya, 22.

78 What might support the above hypothesis of the oral meaning of the message implied through the use of the verb kataba in early Islamic sources relates to the role of the messenger ( $\operatorname{ras} \bar{u} l)$, which could be understood through the huge number of references to messages delivered by messengers. On certain occasions in non-Sufi sources, the phrase "kataba ilayhi ma"..." (lit. "he wrote to him with ...") might have indicated oral messages with short and specific practical purposes (see Aḥmad ibn 'Abd al-Wahhāb Shihāb al-Dīn al-Nuwayrī, Nihāyat al-arab fí funūn al-adab (Cairo: Dār al-Kutub wa-l-Wathā' iq al-Qawmiyya, 2002), 21: 284; Abū al-Baqā' al-Hillī, al-Manāqib al-Mazyadiyya fì akhbār al-mulūk al-asadiyya, ed. Muḥammad 'Abd al-Qādir Khurīsāt and Șālih Mūsā Darādka (Amman: Maktabat al-Risāla al-Hadītha, 1984), 199). The discussion of the roles and merits of the messenger in al-Qalqashandi's Subh al-a sha has more to do with formal letters and it leaves no doubt that messengers had rhetorical merits that enabled them to fulfil the purpose of the letters they were appointed to deliver, particularly when the literal phrasing of the original message was altered on the way to the addressee - see Ahmmad ibn 'Alī al-Qalqashandī, Subh al-a shà fì șinā' at al-inshā (Beirut: Dār al-Kutub al-'Ilmiyya, n.d.), 1: 151. On the general merits of the messengers, see ibid., 6: 344-7

79 Bid' $a$ is an innovation not based on the model behaviour of the Prophet Muhammad. The use of this term as an accusation addressed to Sufis of distancing from that Prophetic model was very common in the sources of early medieval Islam. On the term bid'a and its different usages and meaning in the history of Islam see Vardit Rispler, "Toward a new understanding of the term bid'a", Der Islam: Zeitschrift für Geschichte und Kultur des Islamischen Orients 68, 1991, 320-8. Al-Dhahabī quotes from al-Sulamī's work on Sufi trials (Mihan al-süfiyya) that when the jurists of Balkh heard Ibn al-Faḍl speaking in public on Quranic exegesis they defamed him and accused him of bid' $a$. According to al-Sulamī, this happened because Ibn al-Fadil belonged to the people of hadith (ahl al-hadìth) towards whom those jurists were hostile. He was exiled to Samarqand where he was welcome and highly venerated. See al-Dhahabī, Siyar a lām al-nubalä, 14: 525 . 
Shams al-Dīn al-Dhahabī, using al-Sulamī as his authority, indicates that al-Hīrī is alleged to have said: "Would I have enough power, I would travel to my brother Muhammad ibn al-Faḍl so that I can enjoy the delight of seeing him". ${ }^{80}$ This implies that if the story of the exchange of letters between these two personalities was fabricated, this fabrication was grounded on the fact that geographically they lived in two distant locations.

\section{Conclusion}

This paper introduced exchanges of letters and correspondence between Sufis during Sufism's formative period as documents with social, interpersonal and historical values. By social, interpersonal and historical values I refer to contexts and backgrounds that pushed forward the addressment of letters, as well as the textual nuances that, when cross-checked with relevant data provided in other sources, could demonstrate certain aspects of Sufis' living realities. A deep analysis of the exchange of letters between al-Junayd and Yūsuf ibn al-Husayn, for instance, could provide an extraordinary portrait of some aspects of the relationships between Baghdadi Sufis (the șufiyya) and Sufis of the East during the third/ninth century. The distant relationship between the two personalities as implied in their letters provides an interesting facet of the debate between the Sufi piety of Iraq and that of other parts of Muslim territories, especially the malāmatiyya trend of Khurāsān.

Separating rasa $\vec{a}$ il (letters) as literary epistles from $r a s \vec{a}^{\prime} i l$ as actual letters is even more difficult in Sufi contexts than in non-Sufi ones. The literary genre imposes structural constraints which then influence the content; this content contains practical messages flowing from particular historic moments and giving rise to actual letter writing. Though Sufi letters are rarely just personal or private documents, owing to the large amount of space they devote to discussing Sufi conduct, personal and interpersonal features can still be gleaned.

This paper highlights the significance of these documents from two perspectives: the first methodological and the second conceptual-historical.

Using the methodological perspective, this paper emphasized the crucial need for creating a corpus of Sufi letters and pieces of correspondence written in the period between the late ninth and thirteenth centuries between Sufis and, on certain occasions, between Sufis and non-Sufis. A detailed survey of the sources for such material was presented. Questions of transmission and usage of letters by later authors as well as the real circumstances that surrounded the composition of letters or the response letters were also discussed. Very frequently, abstract literary contents concerning Sufi conduct and general manners and beliefs still occupy a prominent place in these letters; this gives these documents a timeless nature. In order to glean interpersonal features, a crosscheck with other types of sources is required. Some examples of this procedure were presented here.

Using the conceptual-historical perspective, questions of content and different expressive forms and styles relating to the changing conditions and historical events in certain relevant letters were discussed. Furthermore, rhetoric, forms 
of argumentation, self-justification and self-representation of the senders and their use of frequent structural features, metaphors and symbols were also analysed. Based on contents, conditions and historical events, the bulk of Sufi letters were categorized and identified differently. Throughout this part of the paper, many sample letters and response letters were analysed to demonstrate the methodological method of treatment as well as the real-life situations reflected in what appear to be literary documents. 